\title{
Aplikasi Monitoring Laporan Aduan Masyarakat pada Desa Kedunggede Kecamatan Lumbir
}

\author{
Gustin Setyaningsih, Heraya Fitra, Hanun Karomatunnisa, Palupi Pandanarum
}

Universitas Amikom Purwokerto, Indonesia

\section{Informasi Artikel}

\section{Article history:}

Received, 1 August 2020

Revised, 3 September 2020

Accepted, 15 September 2020

\section{Kata Kunci:}

Teknologi Informasi Pengaduan Masyarakat

Pemerintah Desa

Aplikasi Mobile

Monitoring Laporan

\section{ABSTRAK}

Teknologi informasi merupakan salah satu hal yang memiliki peranan penting di era saat ini. Perkembangan teknologi semakin pesat setiap tahunnya menciptakan fasilitas-fasilitas sehingga memberikan kemudahan bagi penggunanya. Teknologi informasi secara langsung berdampak pada kehidupan individu dan sosial seperti instansi pemerintah desa. Desa memiliki peran yang sangat strategis dalam memberikan pelayanan kepada publik. Membangun kepercayaan masyarakat atas pelayanan publik yang dilakukan penyelenggara merupakan kegiatan yang harus dilakukan seiring dengan harapan dan tuntutan masyarakat tentang peningkatan pelayanan publik. Pengaduan masyarakat merupakan salah satu upaya untuk membuat masyarakat berperan serta dalam usaha pemerintah meningkatkan pelayanan publik dan penerapan good governance. Masyarakat dapat membantu memberikan informasi kepada pemerintah desa mengenai permasalahanpermasalahan yang ada di Desa Kedunggede seperti keramaian, kriminal dan pelayanan. Pelayanan publik mengenai penerimaan pengajuan aduan dan tanggapan pengaduan di Desa Kedunggede masih bersifat manual. Hal ini menyebabkan masyarakat kurang efektif dalam menyampaikan keluhan yang mengakibatkan keluhan tidak tersampaikan dengan tepat. Maka dalam penelitian ini, kami membangun aplikasi dengan metode pengembangan sistem waterfall yang menerima keluhan atau aduan masyarakat Desa Kedunggede untuk mempermudah penyampaian aduannya.

\section{ABSTRACT}

Information technology is one thing that has an important role in the current era. The development of technology is increasing rapidly every year to create facilities so as to provide convenience for its users. Information technology directly impacts individual and social life such as village government agencies. The village has a very strategic role in providing services to the public. Building public trust in public services carried out by organizers is an activity that must be carried out in line with the expectations and demands of the community regarding improving public services. Public complaints are an effort to make people participate in government efforts to improve public services and implement good governance. The community can help provide information to the village government about problems in Kedunggede Village such as crowds, crime and services. Public services regarding receipt of complaints submissions and responses to complaints in Kedunggede Village are still manual. This causes the community to be less effective in submitting complaints which results in complaints not being conveyed properly. So in this study, we built an application with the waterfall system development method that accepts complaints or complaints from the people of Kedunggede Village to facilitate the delivery of complaints.

This is an open access article under the CC BY-SA license.

\section{Penulis Korespondensi:}

Gustin Setyaningsih,

Program Studi Sistem Informasi,

Universitas Amikom Purwokerto.

Email: gustin@amikompurwokerto.ac.id 


\section{PENDAHULUAN}

Desa adalah kesatuan masyarakat hukum yang memiliki batas-batas wilayah yang berwenang untuk mengatur dan mengurus kepentingan masyarakat setempat. Berdasarkan asal-usul dan adat istiadat setempat yang diakui dan dihormati sistem Pemerintah Negara Kesatuan Republik Indonesia [1]. Masyarakat sebagai makhluk sosial membutuhkan pelayanan yang bersumber dari aduan masyarakat itu sendiri. Untuk itu dalam rangka memberikan pelayanan kepada masyarakat agar terlaksana dengan baik, aparatur pemerintah Desa dapat memainkan perannya secara langsung dan melibatkan diri dalam memberikan pelayanan kepada masyarakat sesuai dengan tugas dan fungsinya agar masyarakat puas dengan pelayanan yang diberikan oleh pemerintah Desa dan pelayanan yang diharapkan dapat berjalan secara optimal.

Whistleblower atau layanan pengaduan masyarakat merupakan layanan yang terciptanya masyarakat yang aman dan sejahtera [2]. Membangun kepercayaan masyarakat atas pelayanan publik yang dilakukan penyelenggara pelayanan publik merupakan kegiatan yang harus dilakukan seiring dengan harapan dan tuntutan seluruh warga negara dan penduduk tentang peningkatan pelayanan public [3] . Pelayanan publik mengenai penerimaan pengajuan aduan dan tanggapan pengaduan di Desa Kedunggede masih bersifat manual. Hal ini menyebabkan masyarakat kurang efektif dalam menyampaikan keluhan yang mengakibatkan keluhan tidak tersampaikan dengan tepat.

Teknologi Informasi merupakan fasilitas yang sangat mempermudah masyarakat dalam memberi dan mendapatkan informasi jika dimanfaatkan dengan baik. Teknologi Informasi telah menyebar dengan cepat dinegara-negara maju tetapi umumnya lambat di negara berkembang. Pengaruh informasi dalam masyarakat ini memunculkan masyarakat baru yang disebut masyarakat informasi. Masyarakat informasi adalah sebuah masyarakat yang terbentuk pasca revolusi industri. Masyarakat informasi sendiri dapat dikatakan sebuah masyarakat yang melambangkan perubahan yang dibawa oleh kemajuan teknologi dan globalisasi menjelang akhir abad ke-20 zaman ini ditandai dengan kecepatan dan ketepatan dalam produksi, transfer, akses, dan penggunaan pengetahuan [4].

Sejak tahun 2015 hingga 2018, secara umum terlihat kecenderungan positif dalam beberapa indikator teknologi, informasi dan komunikasi di Indonesia. Pengguna Teknologi Informasi dan Komunikasi (TIK) dari tahun ke tahun semakin meningkat. Dari sisi komunikasi, pelanggan telepon seluler meningkat setiap 100 penduduk hingga tahun 2017, lalu menurun di tahun 2018 sebesar 121,04. Perkembangan penetrasi internet di Indonesia juga terus mengalami peningkatan yaitu dari 21,98 di tahun 2015 menjadi 39,90 di tahun 2018. Pelanggan aktif mobile broadband meningkat hingga tahun 2017 dan menurun di tahun 2018 menjadi 88,12 per 100 penduduk. Berdasarkan perkembangan indikator Teknologi Informasi dan Komunikasi di Indonesia tahun 2015-2018 [ㄷ] , perkembangan paling pesat terlihat pada penggunaan telepon selular ditunjukkan pada Gambar 1. Perkembangan TIK di Indonesia di bawah ini.

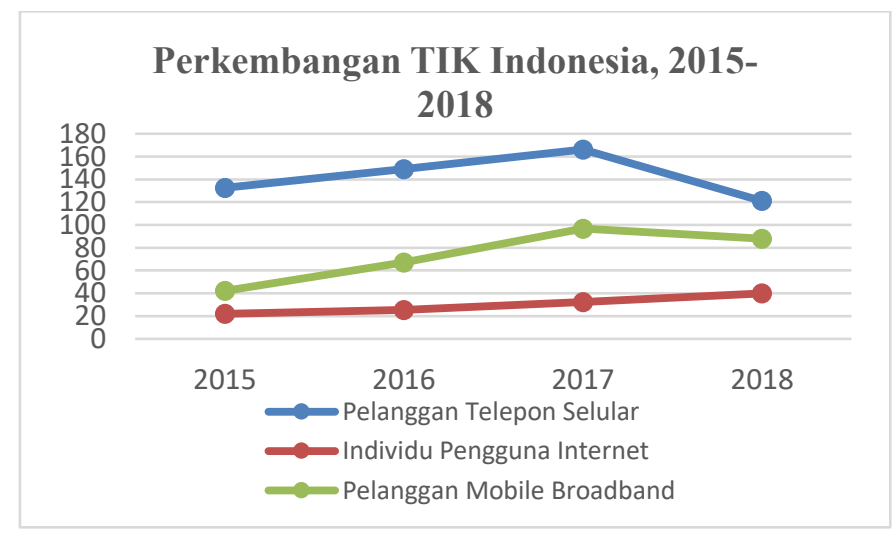

Gambar 1. Perkembangan TIK di Indonesia

Sumber: BPS dan Kemkominfo

Dengan data penggunaan TIK di Indonesia sampai tahun 2018 sebesar 57,33\%. Maka, penelitian ini bertujuan untuk membangun aplikasi mobile yang akan memudahkan masyarakat Desa Kedunggede dalam menyampaikan aduannya melalui aplikasi pengaduan Desa Kedunggede untuk berbagai jenis aduan, contohnya yaitu aduan mengenai alam, infrastuktur, kegaduhan, dan lain-lain. Masyarakat dapat mengunggah foto bukti aduan melalui aplikasi tersebut. Dengan begitu, pemerintahan desa dapat mengetahui aduan-aduan dari masyarakat dengan efektif dan efisien. Android merupakan "Open Mobile Platform” yang dikembangkan oleh Google, secara sederhana Android merupakan sebuah sistem operasi untuk handphone, seperti halnya Symbian atau Windows Phone. Android dikembangkan dari Sistem Operasi Linux, middleware, dan semua aplikasinya 
dibuat dengan menggunakan Java. Perlengkapan penyediaan fitur dalam Android disertakan Standart Development Kid (SDK) dan pengembangan aplikasi dalam platform android disertakan Application Programming Interface (API) [6] .

Beberapa sistem pengaduan telah berhasil dibuat, misalnya aplikasi mobile monitoring laporan pengaduan yang memfasilitasi masyarakat desa untuk memberikan keluhan dan laporan pengaduan yang mereka temui disekitar mereka kepada pihak pemerintah desa yang berwenang dengan cepat, mudah dan terselesaikan serta dapat membantu pemerintah dalam memonitor keluhan masyarakat sehingga pemerintah dengan cepat dapat menanggulangi masalah tersebut. Penelitian yang mencoba menerapkan pengaduan masyarakat berbasis mobile dengan contoh permasalahan melaporkan pungutan liar yang berada di kabupaten Kudus dan menghaslkan aplikasi bernama ALPUKAT (Aplikasi Pengaduan Masyarakat) [7]. Aplikasi mobile berasal dari dua kata, yaitu aplikasi dan mobile. Secara istilah, aplikasi adalah program siap pakai yang dibuat untuk melaksanakan suatu fungsi untuk pengguna atau aplikasi yang lain sedangkan mobile adalah perpindahan dari suatu tempat ke tempat yang lain. Secara lebih lengkap, aplikasi mobile adalah program siap pakai yang melaksanakan fungsi tertentu yang dipasang pada perangkat mobile []ㅡ. Adapun Aplikasi E-Report pengaduan masyarakat. Sistem ini memberitahukan masyarakat atau pelapor tentang status terkini laporan melalui dua cara yaitu anjungan front office yang dapat diakses dengan mengunjungi Ombudsman RI Provinsi Gorontalo dan menggunakan sms dengan mengirim pesan ke nomor Ombudsman RI Provinsi Gorontalo [9]. Aplikasi mobile adalah sebuah aplikasi yang memungkinkan untuk melakukan mobilitas dengan menggunakan perlengkapan seperti PDA (Personal Digital Assistant), telepon seluler atau handphone. Dengan menggunakan aplikasi mobile, maka dapat dengan mudah melakukan berbagai macam aktifitas mulai dari hiburan, berjualan, belajar, mengerjakan pekerjaan kantor, browsing dan lain sebagainya [10].

Sistem Informasi Pengaduan Masyarakat Program Keluarga Harapan (SIPM - PKH), Sistem pengaduan ini dapat mengakomodasi segala jenis pengaduan terkait dengan PKH dan penanganan penyelesaiannya [11] . Aplikasi mobile pengaduan masyarakat pada Dinas Perhubungan Kota Malang menggunakan fitur Location Based Service berbasis android. Aplikasi pengaduan masyarakat Kota Malang untuk melaporkan keluhan pada Dinas Perhubungan Kota Malang dan dapat membantu Dinas Perhubungan dalam menindaklanjuti keluhan dengan cepat dan tanggap [12]. Pengaduan masyarakat merupakan bentuk ungkapan ketidakpuasan masyarakat atas kualitas pelayanan yang diterima yang sering berujung lahirnya tuntutan publik, seringkali dipandang sebagai hal yang buruk bagi kehidupan suatu organisasi, termasuk birokrasi [13]. Beberapa sistem pengaduan telah berhasil dibuat. Salah satu kegunaan dari teknologi internet saat ini adalah untuk akses informasi. Masyarakat dapat akses informasi yang berkembang melalui internet dengan mudah dan up to date. Mulai perkembangan informasi dari masyarakat biasa sampai yang berkembang dari orang-orang penting didunia sekalipun. Dari informasi tersebut masyarakat menjadi makin mudah mencari pengetahuan mulai dari yang mudah maupun yang sulit. Masyarakat juga dengan mudah mengetahui perkembangan informasi yang berkembang di kalangan pemerintah. Dari hal tersebut, menjadikan masyarakat semakin kritis terhadap pemerintah. Kritisnya masyarakat juga membantu pemerintah dalam mengevaluasi program kerja yang mereka jalankan [14]. Pengaduan masyarakat merupakan suatu bentuk partisipasi untuk ikut berperan dalam membangun lingkungannya serta sebagai bentuk pengawasan terhadap kinerja instansi pemerintahan. Laporan maupun aspirasi masyarakat dapat dipergunakan sebagai bahan masukan untuk mengevaluasi kebijakan dan peraturan yang telah dibuat atau peraturan yang telah dilaksanakan dan untuk mengetahui masalah yang ada didalam masyarakat secara efektif, cepat dan up to date serta dapat langsung memberikan solusi dan jalan keluarnya [15].

\section{METODE PENELITIAN}

Pada tahapan awal yaitu melakukan pengumpulan data dengan cara beberapa pertanyaan yang terkait dengan kendala yang dihadapi. Wawancara yang dilakukan dengan kegiatan tanyajawab secara lisan langsung kepada Bapak Sutomo selaku Kepala Desa Kedunggede dan Bapak Suroso selaku Ketua BPD (Badan Permusyawaratan Desa). Peneliti mendapatkan permasalahan seperti aduan dari masyarakat dari segi bantuan masyarakat yang tidak tepat sasaran. Melakukan observasi dilakukan dengan mengamati secara langsung masyarakat Desa Kedunggede yang nantinya akan menggunakan aplikasi pengaduan Desa Kedunggede ini. Saat ini masyarakat masih menggunakan formulir berupa kertas dalam melakukan pengaduan mereka kepada pemerintahan desa. Metode kepustakaan dilakukan untuk memperkuat landasan teori penelitian ini yaitu dengan memanfaatkan beberapa jurnal dan buku yang dapat melengkapi teori-teori yang dibutuhkan dalam penelitian ini. Teori tersebut diantaranya adalah isi dari undang-undang tentang desa, isi dari undang-undang tentang pelayanan publik, pengertian aplikasi mobile, pengertian pengaduan masyarakat. Peneliti mengumpukan referensi berupa buku, jurnal penelitian yang terkait dan buku pemerintahan desa khususnya pengaduan kepada masyarakat.

Gambar 2. Alur penelitian, merupakan tahapan penelitian dari awal hingga akhir pelaksanaan penelitian yang meliputi Pengumpulan Data, Metode Pengembangan Sistem dan Pengujian Sistem. 


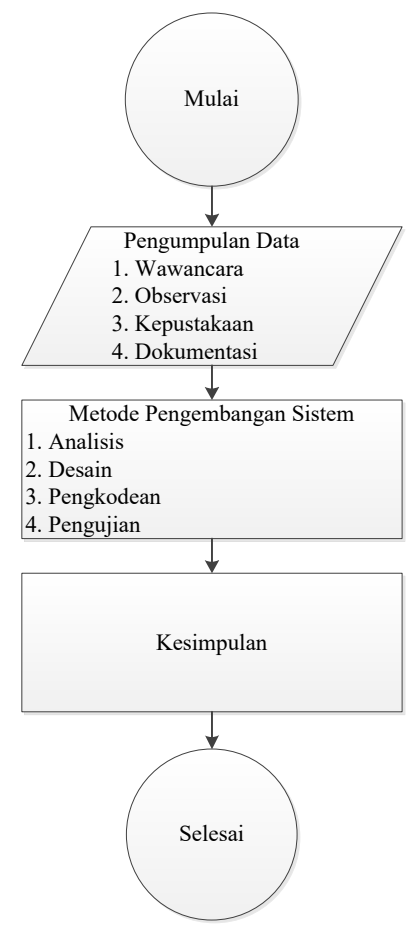

Gambar 2. Alur penelitian

Terakhir dokumentasi dilakukan dengan menggunakan bukti-bukti dari informasi yang akurat. Bukti pada metode dokumentasi ini yaitu dengan foto formulir aduan dari masyarakat Desa Kedunggede. Metode pengembangan sistem aplikasi pengaduan masyarakat Desa Kedunggede ini menggunakan metode waterfall karena melakukan secara sistematis dan berurutan dalam membangun suatu sistem. Proses metode waterfall yaitu proses pengembangan perangkat lunak berurutan dan terorganisir. Sistem yang dihasilkan akan berkualitas baik karena setiap pelaksanaan tahapannya harus terselesaikan dengan lengkap sebelum melangkah ke tahapan berikutnya [16]. Tahapan dari metode waterfall adalah:

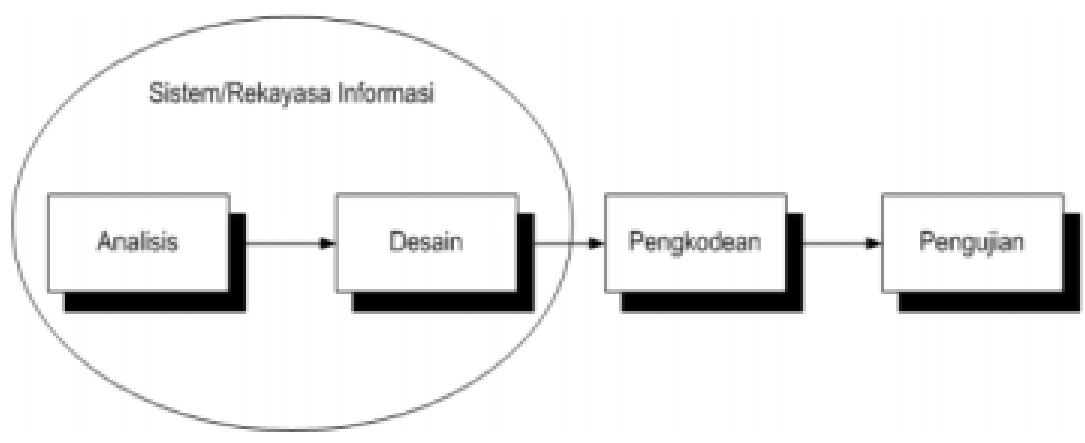

Gambar 3. Sumber: Sukamto dan Shalahuddin (2016)

Berdasarkan Gambar 3. Metode Waterfall, diawali dengan Analisis Kebutuhan Perangkat Lunak adalah proses untuk mendapatkan informasi, mode, spesifikasi tentang perangkat lunak yang diinginkan klien/pengguna. Kedua belah pihak, yaitu klien dan pembuat perangkat lunak terlibat aktif dalam tahap ini. Informasi dari klien yang menjadi acuan untuk melakukan desain perangkat lunak. Kemudian Desain Perangkat Lunak adalah Proses beberapa langkah yang fokus pada desain pembuatam program perangkat lunak termasuk struktur data, arsitektur perangkat lunak, merepresentasikan antar muka dan prosedur pengkodean. Desain perangkat lunak yang dihasilkan pada tahap ini juga perlu di dokumentasikan. Selannjutnya Pengkodean (Penulisan Kode Program) guna menerjemahkan desain dengan penulisan kode program dengan bahasa pemrograman ke dalam program sistem. Hasil dari tahap ini adalah program Komputer sesuai dengan desain yang telah dibuat pada tahap desain. Terakhir adalah pengujian berfokus pada perangkat lunak dari segi logik dan fungsional serta memastikan bahwa semua bagian sudah diuji. Hal ini dilakukan untuk meminimalisir kesalahn (error) dan memastikan keluaran yang dihasilkan sesuai dengan yang diinginkan. 


\section{HASIL DAN ANALISIS}

Berdasarkan Gambar 2. Metode waterfall, Analisis Kebutuhan Perangkat Lunak megnhasilkan data atau informasi sebagai kebutuhan aplikasi Tuan Desa. Data atau informasi peneliti dapatkan dengan wawancara langsung kepada Kepala Desa, Desa Kedunggede. Peneliti mendapatkan informasi mengenai aduan masyarakat yang belum tepat sasaran dan masih menggunakan formulir kertas dalam mengajukan aduan ke pemerintahan desa. Kebutuhan fungsional dari Aplikasi Tuan Desa adalah menampilkan Splash screen. Form login terdiri dari input username dan password. Tombol login untuk masuk aplikasi dan menampilkan halaman utama. Tombol lupa kata sandi digunakan untuk mereset kata sandi baru bagi user yang lupa dengan kata sandi sebelumnya. Aplikasi memiliki 3 tombol utama yaitu home, menu, dan profile. Pada halaman utama/ home terbagi menjadi dua bagian, yaitu berita terkini dan berita aduan. Pada menu terdapat form aduan untuk mengajukan aduan masyarakat. Pada profile untuk mengedit biodata user.

Kemudian tahap desain merupakan translasi dari tahap analisis kebutuhan ke representasi desain agar dapat diimplementasikan menjadi program pada tahap selanjutnya. Pada tahap ini menghasilkan desain sistem berupa use case diagram, activity diagram, sequence diagram, dan class diagram dari bahasa pemodelan UML (Unified Modelling Language). Sedangkan tahap Coding (pengkodean/ penulisan program) merupakan implementasi code dari desain sistem yang telah dibuat. Hasil tampilan antarmuka dari sistem aplikasi Tuan Desa seperti Form Login.

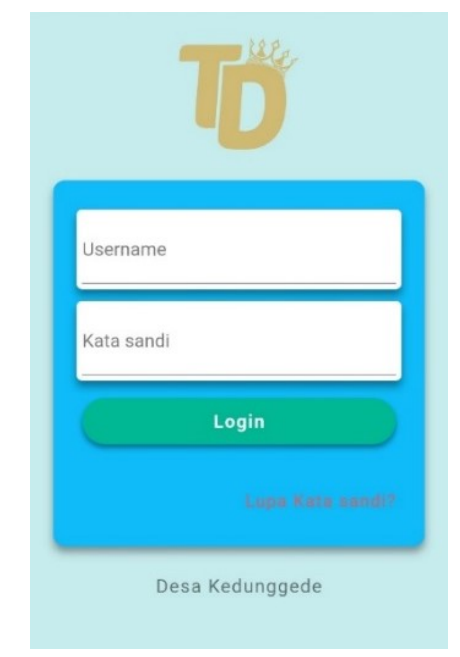

Gambar 3. Form Login Tuan Desa

Gambar 3. Form Login Tuan Desa menunjukkan tampilan login dari aplikasi Tuan Desa. Sebelum user/warga Desa Kedunggede melakukan login, user harus memiliki akun dengan cara mendaftar melalui admin dengan menyerahkan fotocopy KK (Kartu Keluarga). User (warga desa)/ admin melakukan login dengan cara memasukkan username berupa NIK dan password, maka aplikasi Tuan Desa menampilkan halaman utama.

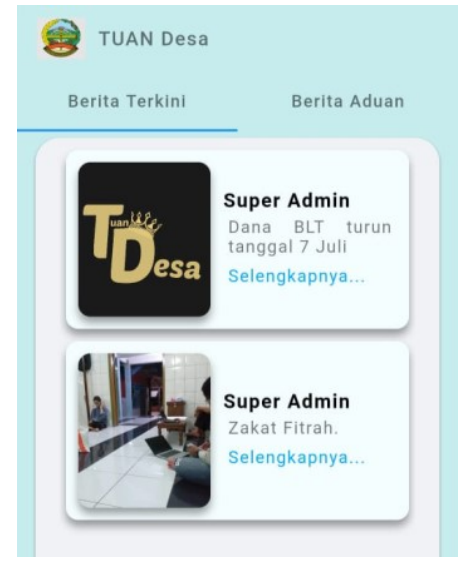

Gambar 4. Halaman Utama (Berita Terkini) 
Gambar 4. Halaman Utama (Berita Terkini) menampilkan halaman utama jika user telah berhasil login aplikasi Tuan Desa. Pada halaman utama terdiri dari berita terkini dan berita aduan. Berita terkini menampilkan berita atau informasi terbaru seputar Desa Kedunggede. User dapat memberikan 'like' untuk setiap post yang ada.

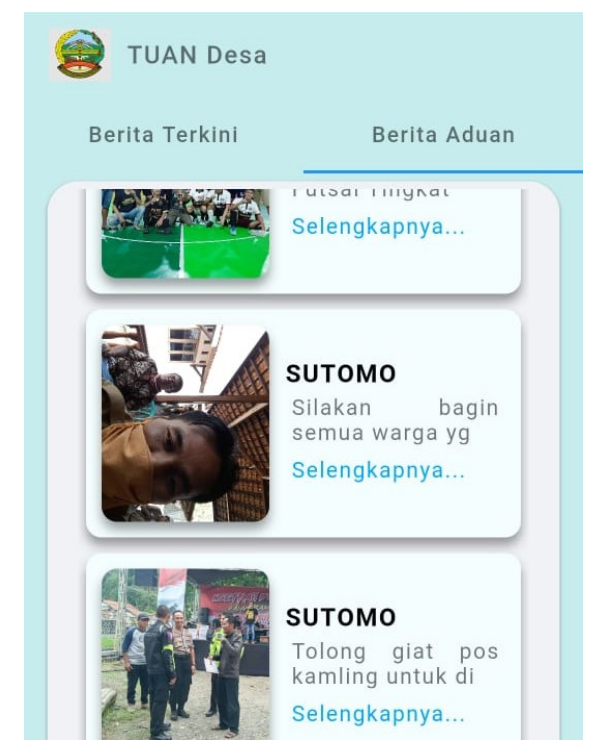

Gambar 5. Halaman Utama (Berita Aduan)

Gambar 5. Halaman Utama (Berita Aduan) menampilkan halaman utama bagian berita aduan. Pada halaman ini menampilkan hasil aduan yang telah diajukan user lain/ warga Desa Kedunggede. User dapat memberikan 'like' dan komentar untuk setiap post yang ada.

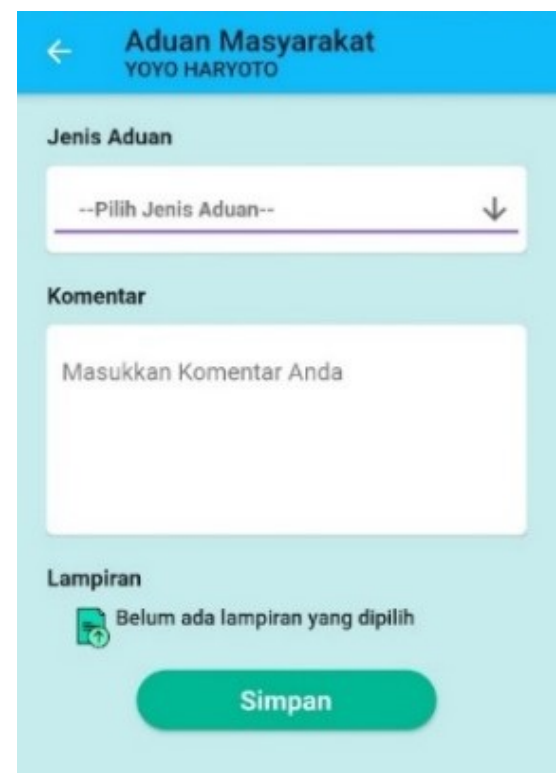

Gambar 6. Form Aduan Masyarakat

Gambar 6. Form Aduan Masyarakat menampilkan formulir untuk pengajuan aduan dari warga Desa Kedunggede. Formulir ini terdiri dari jenis aduan, komentar, dan lampiran. Jenis aduan meliputi aduan keramaian, kriminal dan pelayanan. User dapat memberikan komentar dan memberikan gambar sebagai bukti aduan yang diajukan. Hasil dari formulir aduan yang diajukan dan telah disimpan akan ditampilkan pada halaman utama (berita aduan). 


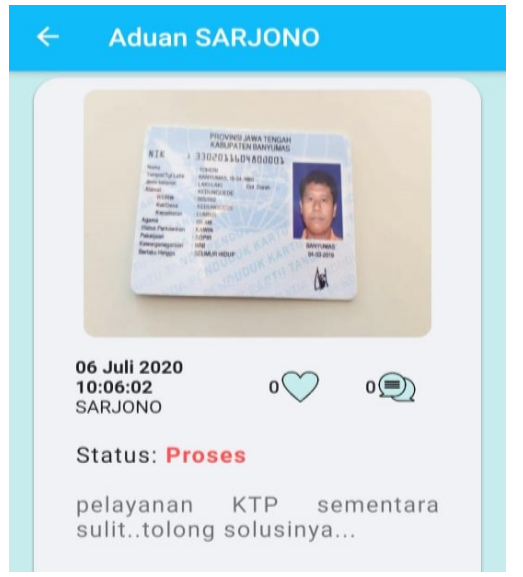

Gambar 7. Hasil Aduan Masyarakat

Gambar 7. Hasil Aduan Masyarakat menampilkan hasil dari aduan yang telah diajukan warga Desa Kedunggede. Selain itu juga terdapat fitur Suka atau Like yang bersimbol Love dan bisa memberikan komentar atas aduan tersebut yang dilambangkan simbol balon teks. Terdapat juga hasil tampilan antarmuka dari sistem website admin Tuan Desa seperti halaman dashboard admin

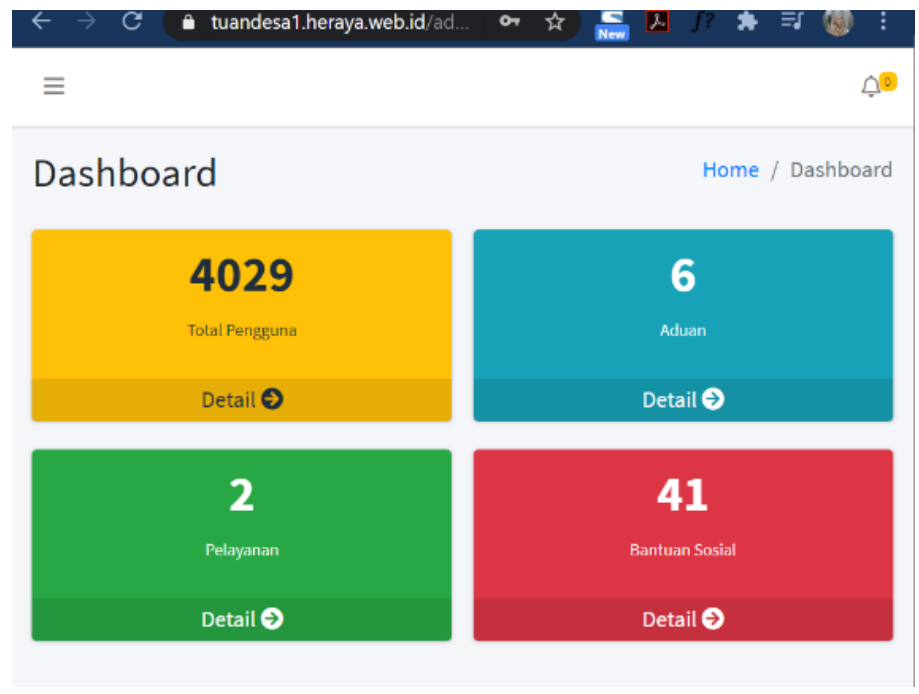

Gambar 8. Dashboard Admin

Gambar 8. Dashboard Admin, menampilkan total pengguna, jumlah pengajuan aduan masyarakat, pelayanan dan bantuan sosial.

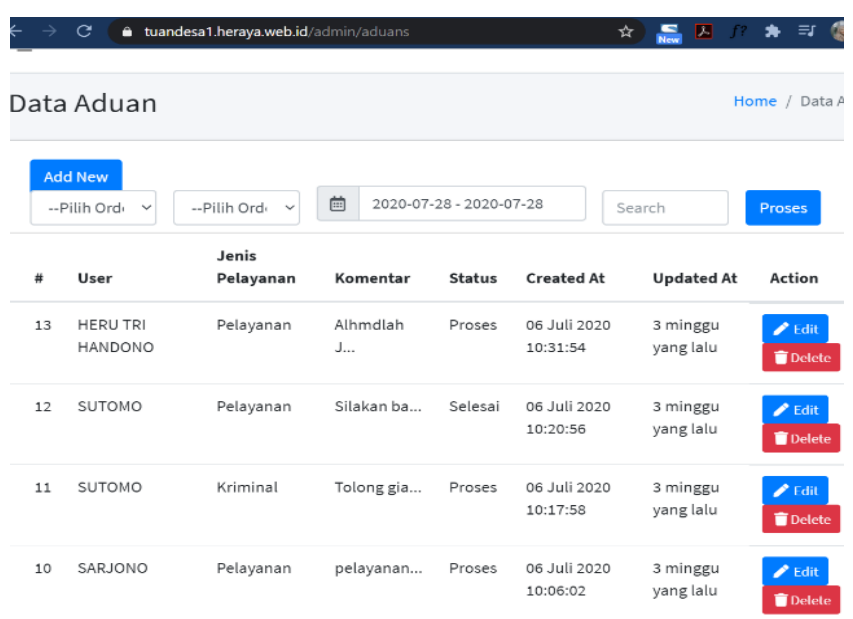

Gambar 9. Data Aduan (admin) 
Gambar 9 menampilkan hasil aduan yang telah diajukan warga Desa Kedunggede. Admin dapat mengedit untuk mengubah status aduan dan menghapus data aduan tersebut. Tahap pengujian bertujuan untuk memastikan bahwa aplikasi siap dipakai dalam keadaan baik dan untuk mengetahui kelemahan dari sistem. Pengujian pada aplikasi Tuan Desa menggunakan metode Black Box. Black Box Testing berfokus pada spesifikasi fungsional dari perangkat lunak. Penguji dapat mendefinisikan kumpulan kondisi input sistem dan melakukan pengujian pada spesifikasi fungsional program [17].

Tabel 1 Hasil Pengujian dari Aplikasi Tuan Desa

\begin{tabular}{|c|c|c|c|}
\hline Item Uji & Skenario Pengujian & Hasil yang diharapkan & Hasil Kenyataan \\
\hline Tampilan awal & $\begin{array}{l}\text { Memilih launcher icon } \\
\text { aplikasi }\end{array}$ & $\begin{array}{l}\text { Menampilkan Splash Screen lalu } \\
\text { menampilkan tampilan login }\end{array}$ & Sesuai harapan \\
\hline \multirow[t]{3}{*}{ Proses Login } & $\begin{array}{l}\text { Input username dan } \\
\text { password benar }\end{array}$ & Menampilkan halaman utama & Sesuai harapan \\
\hline & $\begin{array}{l}\text { Input } \quad \text { username } \\
\text { password salah }\end{array}$ & Akan muncul pesan error & Sesuai harapan \\
\hline & $\begin{array}{l}\text { Username/ password } \\
\text { belum diisi atau salah }\end{array}$ & Akan muncul pesan error & Sesuai harapan \\
\hline Halaman Utama & Memilih home & Menampilkan Halaman Utama & Sesuai harapan \\
\hline \multirow[t]{2}{*}{ Berita Aduan } & $\begin{array}{l}\text { Memilih berita aduan pada } \\
\text { home }\end{array}$ & $\begin{array}{l}\text { Menampilkan berita aduan yang } \\
\text { telah diajukan warga lain }\end{array}$ & Sesuai harapan \\
\hline & $\begin{array}{l}\text { Memberi like dan komentar } \\
\text { pada Berita Aduan }\end{array}$ & $\begin{array}{l}\text { Bertambahnya jumlah angka di } \\
\text { samping icon like dan } \\
\text { menampilkan komentar yang telah } \\
\text { dikirim dan atau komentar warga } \\
\text { lain }\end{array}$ & Sesuai harapan \\
\hline \multirow[t]{2}{*}{ Form Aduan } & Memilih menu form aduan & Menampilkan menu form aduan & Sesuai harapan \\
\hline & $\begin{array}{l}\text { Input jenis } \begin{array}{r}\text { aduan, } \\
\text { komentar, lampiran } \\
\text { gambar, lalu klik simpan }\end{array} \\
\end{array}$ & $\begin{array}{l}\text { Data form aduan yang telah diisi, } \\
\text { muncul pada home bagian Berita } \\
\text { Aduan }\end{array}$ & Sesuai harapan \\
\hline
\end{tabular}

Dari hasil pengujian yang dilakukan dapat disimpulkan fungsi dari fitur-fitur pada aplikasi Tuan Desa dapat berjalan dengan benar dan sesuai dengan harapan yang dicapai.

\section{KESIMPULAN}

Dari hasil perancangan aplikasi pengaduan Desa Kedunggede dengan menggunakan metode pengembangan waterfall, dapat diambil kesimpulan bahwa aplikasi Tuan Desa adalah aplikasi mobile sebagai platform dalam melayani masyarakat Desa Kedunggede khususnya mengenai pengaduan. Aplikasi Tuan Desa ini dapat membantu kinerja aparatur desa dalam menanggapi pengaduan dari masyarakat dengan lebih efektif dan efisien dibandingkan dengan cara sebelumnya yang masih manual. Dengan adanya aplikasi Tuan Desa dapat mengatasi masalah masyarakat dalam menyampaikan aduan ke pemerintahan desa dengan efektif dan efisien. Dari hasil pengujian yang didapatkan bahwa seluruh fungsi fitur pada aplikasi Tuan Desa dapat berjalan dengan benar dan sesuai dengan harapan yang dicapai peneliti.

\section{UCAPAN TERIMA KASIH}

Peneliti mengucapkan terima kasih kepada semua pihak terutama Universitas Amikom Purwokerto yang telah mendukung dalam penyelesaian penelitian PDMA (Penelitian Dosen Muda Amikom) ini dalam bentuk dukungan finansial, waktu, motivasi, dan pengetahuan. 


\section{REFERENSI}

[1] Republik Indonesia, "Undang-Undang Nomor 6 Tentang Desa.” Sekretariat Negara, Jakarta, 2014.

[2] D. S. Darmawan, D. Ruhyadi, and Kuswinanti, "Aplikasi Layanan Pengaduan Masyarakat Berbasis Android," in Seminar Nasional Rekayasa dan Teknologi, 2019, pp. 40-44.

[3] S. W. Mursalim, "Analisis Manajemen Pengaduan Sistem Layanan Sistem Aspirasi Pengaduan Online Rakyat (LAPOR) di Kota Bandung," Jurnal Ilmu Administrasi: Media Pengembangan Ilmu dan Praktek Administrasi, vol. 15, no. 1, pp. 1-17, Jun. 2018.

[4] D. A. Gammayani, I. H. Nabawi, and M. I. Alfatih, "Pemanfaatan Teknologi Informasi dan Komunikasi dalam Koordinasi antara Perpustakaan Nasional dengan Perpustakaan Provinsi," Record and Library Journal, vol. 1, no. 2, pp. 120-128, 2015.

[5] "Indeks Pembangunan Teknologi, Informasi, dan Komunikasi 2018," BPS RI, 2018. .

[6] Kosidin and R. N. Farizah, "Pemodelan Aplikasi Mobile Reminder Berbasis Android," in Seminar Nasional Teknologi Informasi dan Komunikasi, 2016, pp. 271-280.

[7] A. Y. Pratama, I. A. Prabowo, and A. Normassari, "(Alpukat) Aplikasi Pengaduan Masyarakat untuk Melaporkan Kejadian Pungutan Liar di Kabupaten Kudus Berbasis Android," Simetris : Jurnal Teknik Mesin, Elektro dan Ilmu Komputer, vol. 8, no. 2, pp. 399-404, 2017.

[8] S. Mukmin and P. Inggih, "Rancang Bangun Aplikasi Berbasis Mobile untuk Navigasi ke Alamat Pelanggan TV Berbayar (Studi Kasus: Indovision Cabang Pekanbaru)," Jurnal Rekayasa dan Manajemen Sistem Informasi, vol. 2, no. 1, pp. 82-94, 2016.

[9] R. H. Dai, L. Hadjaratie, and N. F. Bouti, "Rancang Bangun Aplikasi E-Report Pengaduan Masyarakat Design Public Complaint E-Report Application," Jurnal Electronics, Informatics and Vocational Education, vol. 2, no. 1, pp. 65-73, 2017.

[10] A. Satyaputra and E. maulian Aritonang, Java for Beginners with Eclipse 4.2 Juno. Jakarta: Elexmedia Komputindo, 2010.

[11] A. Anofrizen, "Program Keluarga Harapan Kota Pekanbaru ( Studi Kasus: Dinas Sosial dan Pemakaman Kota Pekanbaru )," Jurnal Ilmiah Rekayasa dan Manajemen Sistem Informasi, vol. 3, no. 1, pp. 97-101, 2017.

[12] F. Eriyani, B. Priyambadha, and H. Nurwarsito, "Pengembangan Aplikasi Mobile Pengaduan Masyarakat pada Dinas Perhubungan Kota Malang Menggunakan Fitur Location Based Service Berbasis Android," Jurnal Pengembangan Teknologi Informasi dan Ilmu Komputer, vol. 3, no. 4, pp. 4083-4091, 2019.

[13] S. Suryadi, "Penanganan Keluhan Publik Pada Birokrasi Dinas Perijinan," Journal Universitas Airlangga, vol. Vol. 23 No, 2010.

[14] R. Siti, W. Ida, and K.Muhammad, "Pengembangan Sistem Informasi Pengaduan Masyarakat Kabupaten Jepara Berbasis Web," Jurnal Transistor Elektro dan Informatika, vol. 2, no. 2, pp. 111123, 2017.

[15] A. W. P. Widayat, "Rancang Bangun Aplikasi Quick Response Berbasis Web dan SMS Gateway dalam Melayani Pengaduan Masyarakat," Fakultas Dian Nuswantoro, Universitas Dian Nuswantoro, vol. 1, pp. 3-4, 2014.

[16] C. Tristianto, "Penggunaan Metode Waterfall Untuk Pengembangan Sistem Monitoring dan Evaluasi Pembangunan Pedesaan," Jurnal Teknologi Informasi ESIT, vol. 12, no. 1, pp. 41-56, 2018.

[17] M. S. Mustaqbal, R. F. Firdaus, and H. Rahmadi, "Pengujian Aplikasi Menggunakan Black Box Testing Boundary Value Analysis (Studi Kasus : Aplikasi Prediksi Kelulusan SNMPTN),” vol. 1, no. 3, pp. 31-36, 2015. 
